\title{
SISTEM CERDAS PENENTUAN PEMBERIAN KREDIT DENGAN MENGGUNAKAN METODE NAIIVE BAYES CLASIFICATION
}

\author{
'Suriana, ${ }^{2}$ Samsudin \\ 1,2,3 Program Studi Sistem Informasi, Fakultas Teknik dan Ilmu Komputer \\ Universitas Islam Indragiri (UNISI) \\ Jl. Provinsi No. 01 Tembilahan Hulu, Indragiri Hilir, Riau - Indonesia \\ Email:surianajambi2018@gmail.com,samsudin_as_ad@yahoo.com
}

\begin{abstract}
ABSTRAK
Kebutuhan akan analisis mengenai penentuan pemberian kredit di BUMDES Desa Pekantua menjadi alasan dilakukannya penelitian terhadap penentuan pemberian kredit kepada nasabah. Selain itu riset ini juga diharapkan dapat mengurangi resiko kredit yang telah banyak ditemukan sehingga dapat menghindari kehancuran suatu instansi. Penentuan pemberian kredit secara manual sudah menimbulakan masalah terutaama dalam pengembalian pinjaman disebabkan oleh kreteria nasabah yang berbeda pada setiap nasbah yang diberikan kredit. Untuk itu dibutuhkan sebuah sistem cerdas penentuan pemberian kredit salah satunya dengan menggunakan strategi data mining dan pengimplementasian Naives Bayes Clssification. Cara kerja dengan metode naïve bayes adalah akan melakukan pemilihan antara dua kelas yaitu kelas Yes dan kelas No sesuai dengan nilai perhitungan yang lebih besar. Data akan dikolompokan menjadi dua bagian yaitu data training dan data testing. Data training digunakan sebagai pembelajaran bagi sistem sedangkan data testing digunakan sebagai data baru untuk mengukur tingkat keakurasiaan suatu sistem. Penelitian ini menggunakan metode keakurasian matriks konfusion dalam menghitung keakuratan sistem dengan hasil yang didapat setelah dilakukan pengujian yaitu $63,50 \%$.
\end{abstract}

Kata Kunci: Sistem Cerdas, Kredit, Naïve Bayes Clasification

\section{PENDAHULUAN}

BUMDES adalah kepanjangnan dari badan usaha milik desa yang bergerak dibidang peminjaman dana atau pengkreditan. Adapun dana tersebut dialokasikan untuk setiap nasabah yang membutuhkan dana khususnya bagi nasabah setempat. Kebutuhan akan dana terutama bagi para pebisnis yang ingin mengembangkan uasahanya atau mungkin saja memulai usaha baru dan masalah lainnya. Mereka pasti memerlukan dana yang tidak sedikit jumlahnya. Untuk itu BUMDES memberikan pinjaman dana bagi setiap nasabah. Besar kecilnya jumlah dana yang dipinjamakannya berdasarkan jaminan apa yang dberikan oleh nasabah bisa berupa mobil, sepeda motor dan sebagainya yang memiliki daya jual kembali.

Akan tetapi jaminan yang diberikan nasabah tidak menjamin melakukan pembayaran angsuran yang baik pada tiap jatuh tempo. Seperti bebarapa contoh ada nasabah yang menjual barang jaminannya kepada orang lain dan ada pula yang kabur setelah meminjam dana sehingga menyulitkan para karyawan BUMDES untuk melakukan perundingan sehingga menghambat pelaporan. Ada pula yang pada pembayaran awal sangat lancar dan kemudian untuk pembayaran terakhir mengalami tunggakan yang kadang mencapai tiga bulan. Ada pula nasabah yang pembayaran awal agak kurang lancar namun pada pembayaran akhir sangatlah baik terkadang hal tersebut dilakukan hanya untuk menarik simpati karyawan instansi untuk sorang nasabah dapat melakukan pinjaman berikutnya.

Untuk mengatasi hal tersebut.Dirancanglah sebuah sistem cerdas penentuan pemberian kredit menggunakan metode naïve bayes clasification.Didalam sistem ini akan dinilai bagaimana kualaitas nasabah tersebut apakah tergolong dapat diberikan pinjaman dana berupa kredit. Untuk keefktifan nasabah dalam membayar angsuran perbulannya dengan memasukakan data-data yang diminta pada sistem seperti pendapatan, tanggungan/anak dan sebagainya kemudian akan

Suriana, Sistem Cerdas Penentuan Pemberian Kredit Dengan Menggunakan Metode Naïve Bayes Clasification 
diproses dan akan mendapatkan kualitas nasabah tersebut. Dengan adanya sistem ini diharapkan mampu menganalisa nasabah sejak dini sehingga dapat dicarikan solusi supaya tidak terjadi kredit macet.

\section{TINJAUAN LITERATUR}

Sistem adalah suatu jaringan kerja dari prosedur-prosedur yang saling berhubungan berkumpul sama-sama untuk melakukan suatu kegiatan atau untuk mnyelesaikan suatu sasaran tertentu [9].selain itu juga sistem diartikan sebagai susunan seperti halnya dalam kata sistem syaraf berarti susunan syaraf, sistem jaringan berarti susunan jaringan dan sebagainya [3]. Untuk membangun sebuah sistem dibutuhkan data. Data didefinisikan sebagai deskripsi tentang benda, kejadian, aktivitas dan transaksi yang tidak mempunyai makna atau tidak berpengaruh secara langsung kepada pemakainya [10].

Kredit berasal dari kata credere yang artinya kepercayaan maksudnya apabila seseorang memperolah kredit, berarti memproleh kepercayaan[13]. Sedangkan menurut Zelfriyenni(2014) kredit adalah penyedian uang atau tagihan yang dapat dipersamakn dengan itu, berdasarka kesepakatan pinjam meminjam antara bank dengan pihak lain yang mewajibkan pihak peminjam untuk melunasi hutangnya setelah jangka waktu tertentu dengan bunga, imbalan atau pembagian hasil keuntungan[8].

Kreterai penilaian kredit seperti sifat atau watak seseorang, kemampuan membayar, penggunaan dana, kondisi sosial ekonomi dan politik serta jaminan yang diajukan diperlukan untuk memberikan informasi mengenai itikad dan kemampuan membayar seorang nasabah[15]. Data mining merupakan suatu cara dalam penggalian informasi dari sejumlah data yang biasanya tersimpan dalam apositori dengan menggunakan teknologi pengenalan pola, statistik dan matematika[1].

Sedangkan menurut Ndaumanu(2014) data mining adalah proses yang menggunakan teknik statistik matematika, kecerdasan buatan, dan machine training untuk mengekstraksi dan mengidentifikasi informasi yang bermanfaat dan pengetahuan yang terkait dari berbagai data base besar[2].dalam penerapannya data mining memerlukan berbagai perangkat lunak analisisdata agar dapat digunakan untuk membuat prediksi dan klasifikasi dengan akurat[6]. Klasifikasi merupakan suatu pekerjaan menilai objek data untuk memasukkannya kedalam kedalam kelas tertentu dari kelas yang tersedia[7].

Sedangkan klasifikasi menurut Annur(2018) klasifikasi adalah proses penemuan model (atau fungsi) yang menggambarkan dan membedakan kelas data atau konsep yang bertujuan agar bisa

digunakan untuk memprediksi kelas dari objekyang lebel kelasnya tidak diketahui[14]. Nialai accuracy adalah persentase dari jumlah record data yang diklasifikasikan secara baik dan benar dengan menggunakan suatu algoritma dan dapat membuat klasifikasi setelah dilakukan pengujian pada hasil klasifikasi tersebut[16].

\section{METODOLOGI PENELITIAN}

\subsection{Pengumpulan data dan pengolahan data}

Penelitian ini mengambil data dari intansi Bumdes. Adapun data tersebut terbagi atas bebrapa atribut dan sub atribut seperti pada tampilan tabel dibawah ini. 
Tabel 1 Atribut dan Sub Atribut yang Digunakan

\begin{tabular}{|c|c|c|}
\hline NO & ATRIBUT & SUB ATRIBUT \\
\hline \multirow{3}{*}{1} & \multirow{3}{*}{ USIA } & $>=18$ \\
\hline & & $>=23$ \\
\hline & & $>=35$ \\
\hline \multirow{4}{*}{2} & \multirow{3}{*}{ STATUS } & Belum Menikah \\
\hline & & Menikah \\
\hline & & Janda/Duda \\
\hline & \multirow{5}{*}{ JUMKLAH TANGGUNGAN } & I orang \\
\hline \multirow{4}{*}{3} & & tidak ada \\
\hline & & 2-3 orang \\
\hline & & $>=3$ orang \\
\hline & & $>=5$ orang \\
\hline \multirow{17}{*}{4} & \multirow{17}{*}{ PEKERJAAN } & PNS \\
\hline & & Jaksa \\
\hline & & Karyawan Kontrak \\
\hline & & Karyawan Tetap \\
\hline & & Karyawan Harian \\
\hline & & Wiraswasta Kecil \\
\hline & & Wiraswasta Menengah \\
\hline & & Wiraswasta Besar \\
\hline & & Dosen \\
\hline & & Dokter/ bidan \\
\hline & & Guru honor \\
\hline & & Pengacara \\
\hline & & Guru Sertifikasi \\
\hline & & Petani \\
\hline & & Asisten rumah tangga \\
\hline & & Ibu rumah tangga \\
\hline & & Pensiun \\
\hline \multirow{3}{*}{5} & \multirow{3}{*}{ JAMINAN } & Rumah \\
\hline & & Sepeda motor \\
\hline & & Tidak ada \\
\hline \multirow{6}{*}{6} & \multirow{6}{*}{ PENGHASILAN } & $<5000.000$ \\
\hline & & $>=500.000$ \\
\hline & & $>=! .000 .000$ \\
\hline & & $>=2.000 .000$ \\
\hline & & $>=3.000 .000$ \\
\hline & & $>=5.000 .000$ \\
\hline
\end{tabular}

\subsection{Persiapan data uji dan data latih}

Kegiatan yang dilakukan pada tahap persiapan data adalah membuat desain tabel-tabel yang ada pada database. Adapun data yang perlu diolah ada dua jenis data yaitu data latih atau training untuk tampilan datanya dapat dilihat pada tabel 2 berikut ini: 
Tabel 2 Data Latih atau Training

\begin{tabular}{|c|c|c|c|c|c|c|c|}
\hline No & STATUS & USIA & $\begin{array}{c}\mathrm{JT} \\
\text { (ORANG) }\end{array}$ & PEKERJAAN & JAMINAN & PENGHASILAN & KELAS \\
\hline 1 & B. Menikah & $>=18$ & tidak ada & tidak ada & tidak ada & $<500.000$ & NO \\
\hline 2 & B. Menikah & & I orang & KK & Motor & $>=500.000$ & YES \\
\hline 3 & Menikah & & tidak ada & KT & mobil & $>=! .000 .000$ & YES \\
\hline 4 & Janda/Duda & & tidak ada & $\mathrm{KH}$ & Sawah & $>=2.000 .000$ & YES \\
\hline 5 & B. Menikah & & tidak ada & WK & Tanah & $>=3.000 .000$ & YES \\
\hline 6 & Menikah & & $>=1$ & WM & tidak ada & $>=5.000 .000$ & NO \\
\hline 7 & Janda/Duda & & I orang & WK & Motor & $<5000.000$ & NO \\
\hline 8 & B. Menikah & & tidak ada & Pengacara & mobil & $>=500.000$ & NO \\
\hline 9 & Menikah & & $2-3$ orang & GS & Sawah & $>=! .000 .000$ & NO \\
\hline 10 & Janda/Duda & & $>=1$ & KK & Tanah & $>=2.000 .000$ & YES \\
\hline 11 & B. Menikah & & tidak ada & Dokter & Rumah & $>=3.000 .000$ & YES \\
\hline 12 & Menikah & & I orang & GS & Motor & $>=5.000 .000$ & YES \\
\hline 13 & Janda/Duda & & tidak ada & petani & mobil & $<500.000$ & NO \\
\hline 14 & B.Menikah & & tidak ada & petani & Sawah & $>=500.000$ & NO \\
\hline 15 & Menikah & & $>=3$ & ART & Tanah & $>=! .000 .000$ & NO \\
\hline 16 & Janda/Duda & $>=23$ & $>=5$ & PNS & Rumah & $>=2.000 .000$ & YES \\
\hline 17 & B. Menikah & & I orang & KK & Motor & $>=3.000 .000$ & NO \\
\hline 18 & Menikah & & tidak ada & KT & mobil & $>=5.000 .000$ & TES \\
\hline 19 & Janda/Duda & & $2-3$ orang & $\mathrm{KH}$ & Sawah & $<500.000$ & NO \\
\hline 20 & B. Menikah & & $>=3$ & WK & Tanah & $>=500.000$ & NO \\
\hline 21 & Menikah & & $>=5$ & WM & Rumah & $>=! .000 .000$ & YES \\
\hline 22 & Janda/Duda & & I orang & WK & Motor & $>=2.000 .000$ & NO \\
\hline 23 & B. Menikah & & tidak ada & Pengacara & mobil & $>=3.000 .000$ & NO \\
\hline 24 & Menikah & & $2-3$ orang & Dosen & Sawah & $>=5.000 .000$ & YES \\
\hline 25 & Janda/Duda & & $>=3$ & Pensiun & Tanah & $<2.000 .000$ & NO \\
\hline 26 & B. Menikah & & $>=5$ & Dokter & Rumah & $>=5,000.000$ & NO \\
\hline 27 & Menikah & & I orang & GS & Motor & $>=! .000 .000$ & NO \\
\hline 28 & Janda/Duda & & tidak ada & petani & mobil & $>=2.000 .000$ & NO \\
\hline 29 & Menikah & & $2-3$ orang & IRT & Sawah & $>=3.000 .000$ & YES \\
\hline 30 & Menikah & & $>=3$ & ART & Tanah & $>=500.000$ & NO \\
\hline 31 & Janda/Duda & $>=35$ & $>=5$ & PNS & Rumah & $>=2.000 .000$ & NO \\
\hline 32 & B. Menikah & & $2-3$ orang & KK & Motor & $>=500.000$ & NO \\
\hline 33 & Menikah & & tidak ada & KT & mobil & $>=! .000 .000$ & YES \\
\hline 34 & Janda/Duda & & $2-3$ orang & $\mathrm{KH}$ & Sawah & $>=2.000 .000$ & NO \\
\hline
\end{tabular}

Data uji merupaka data yang digunakan dalam pengujian sistem. dimana data ini nantinya sebagai data baru bagi sistem karena belum pernah dikenalkan atau dilakukan pembelajaran sebelumnya. Untuk data uji yang digunakan dapat dilihat pada tabel 3 dibaeah ini. 
Tabel 3 Data Uji

\begin{tabular}{llllllll}
\hline No & STATUS & USIA & JT (OIRANG) & PEKERJAAN & JAMINAN & PENGHASILAN & KELAS \\
\hline 1 & Janda/Duda & $>=18$ & tidak ada & KH & Sawah & $>=2.000 .000$ & YES \\
2 & Janda/Duda & $>=18$ & l orang & WKI & Motor & $<500.000$ & NO \\
3 & Menikah & $>=18$ & l orang & GS & Motor & $>=5.000 .000$ & YES \\
4 & Menikah & $>=18$ & $>=3$ orang & ART & Tanah & $>=! .000 .000$ & NO \\
5 & Menikah & $>=23$ & tidak ada & KT & mobil & $>=5.000 .000$ & YES \\
6 & Menikah & $>=23$ & $>=5$ orang & WM & Rumah & $>=! .000 .000$ & YES \\
7 & B. Menikah & $>=23$ & tidak ada & Pengacara & mobil & $>=3.000 .000$ & NO \\
8 & Menikah & $>=23$ & $>=3$ orang & ART & Tanah & $>=500.000$ & NO \\
9 & Menikah & $>=35$ & tidak ada & KT & mobil & $>=1.000 .000$ & YES \\
10 & Janda/Duda & $>=35$ & $2-3$ orang & KH & Sawah & $>=2.000 .000$ & NO \\
11 & Menikah & $>=35$ & $>=5$ orang & WM & rumah & $>=5.000 .000$ & YES \\
12 & Menikah & $>=35$ & l orang & GS & Motor & $>=5.000 .000$ & YES \\
13 & B. menikah & $>=35$ & l orang & KT & motor & $>=3.000 .000$ & NO \\
14 & Janda/Duda & $>=35$ & $2-3$ orang & KH & Sawah & $>=500.000$ & NO \\
15 & Janda/Duda & $>=35$ & $2-3$ orang & KH & Sawah & $>=1.000 .000$ & NO \\
16 & Menikah & $>=60$ & $>=3$ orang & WK & Tanah & $>=500.000$ & YES \\
\hline
\end{tabular}

Keterngan simbol pada tabel

KK : Karyawan Kontrak

KT :Karyawan Tetap

$\mathrm{KH}$ : Karyawan Harian

WK : Wiraswasta Kecil

IRT : Ibu Rumah Tangga

JT : Jumlah Tanggungan

$\begin{array}{ll}\text { WM } & \text { : Wiraswasta Menengah } \\ \text { WB } & \text { : Wiraswasta Besar } \\ \text { GS } & \text { : Guru Sertifikasi } \\ \text { ART } & \text { : Asisten Rumah Tangga } \\ \text { B. Menikah } & \text { : Belum Menikah }\end{array}$

\subsection{Naives Bayes Clasification}

Naïve bayes merupakan teknik prediksi berbasis probabilistik sederhana yang berdasar pada penerapan teoroma bayes (aturan bayes), dengan asumsi independensi (ketidak tergantungan) yang kuat (naif)[5]. Menurut (Husni \&Ardi, 2017), pengklasifikasi bayesian adalah pengklasifikasi statistik dan didasarkan pada teorema bayes. Teori keputusan bayes adalah pendekatan statistik yang fundamental dalam pengenalan pola (pattern recognition), penggunaan algoritma ini dalam hal klasifikasi harus mempunyai masalah yang bisa dilihat statistiknya. Misalkan X adalah set atribut data dan $\mathrm{h}$ kelas variabel dan jika kelas memiliki hubungan dengan atribut maka diperlukan $\mathrm{X}$ dan $h$ sebagai variabel acak dan menangkap hubungan peluang $P(h \mid X)$ ini peluang posterior untuk $h$ dan sebaliknya perior $\mathrm{P}(\mathrm{h})$.

\subsubsection{Naive Bayes Classifier}

Naive Bayes Classifier mengestimasi peluang kelas bersyarat dengan mengasumsikan bahwa atribut adalah independen secara bersyarat yang diberikan dengan label kelas label kelas label kelas y. Asumsi independen bersyarat dapat dinyatakan dalam bentuk:

$P(X \mid Y=y) \prod_{k=1}^{n} P\left(X_{i} \mid Y=y\right)$

dengan tiap set atribut $X=\left\{X_{1}, X_{2}, \ldots . ., X_{d}\right\}$ terdiri dari $d$ atribut.

Suriana, Sistem Cerdas Penentuan Pemberian Kredit Dengan Menggunakan Metode Naïve Bayes Clasification 


\subsubsection{Tahapan algoritma naive bayes}

Adapun tahapan algoritma naïve bayes adalah sebagai berikut:

1. Menyiapkan data training

2. Setiap data dipresentasikan sebagai vektor berdimensi-n yaitu $X=\left(x_{1}, x_{2}, x_{3}, \ldots \ldots . . x_{n}\right)$ $n$ adalah gambaran dari ukuran yang dibuat di test dari $n$ atribut yaitu $A_{1}, A_{2}, A_{3} \ldots . . . . . . . . . ., A_{n}$ $M$ adalah kumpulan kategori yaitu $C_{1}, C_{2}, C_{3}, \ldots \ldots . . . C_{m}$

3. Diberikan data test $X$ yang tidak diketahui kategorinya, maka classifier akan memprediksi bahwa $\mathrm{X}$ adalah milik kategori dengan posterior probability tertinggi berdasarkan kondisi $\mathrm{X}$

Naive bayes classifier menandai bahwa test $X$ yang tidak diketahui tadi ke kategori $C_{1}$ jika dan hanya jika $P\left(C_{i} \mid X\right)>P\left(C_{j} \mid X\right)$ untuk $1 \leq j \leq m, j \neq i$

4. Kemudian kita perlu memaksimalkan $P\left(C_{i} \mid X\right)$

$P\left(C_{i} \mid X\right)=P\left(X \mid C_{i}\right) \cdot P(C)$

$P(X)$

5. Dimana $x$ adalah nilai-nilai atribut dalam sampel $X$ dan probabilitas $P\left(x_{1} \mid C_{i}\right), P\left(x_{2} \mid C_{i}\right), \ldots \ldots$. $\mathrm{P}\left(\mathrm{x}_{\mathrm{n}} \mid \mathrm{C}_{\mathrm{i}}\right)$, dapat diperkirakan dari data training

\section{HASIL DAN PEMBAHASAN}

Dari penelitian yang dilakukan adapun hasil tampilan terakhir dari sistem dapat dilihat pada gambar 1 berikut :

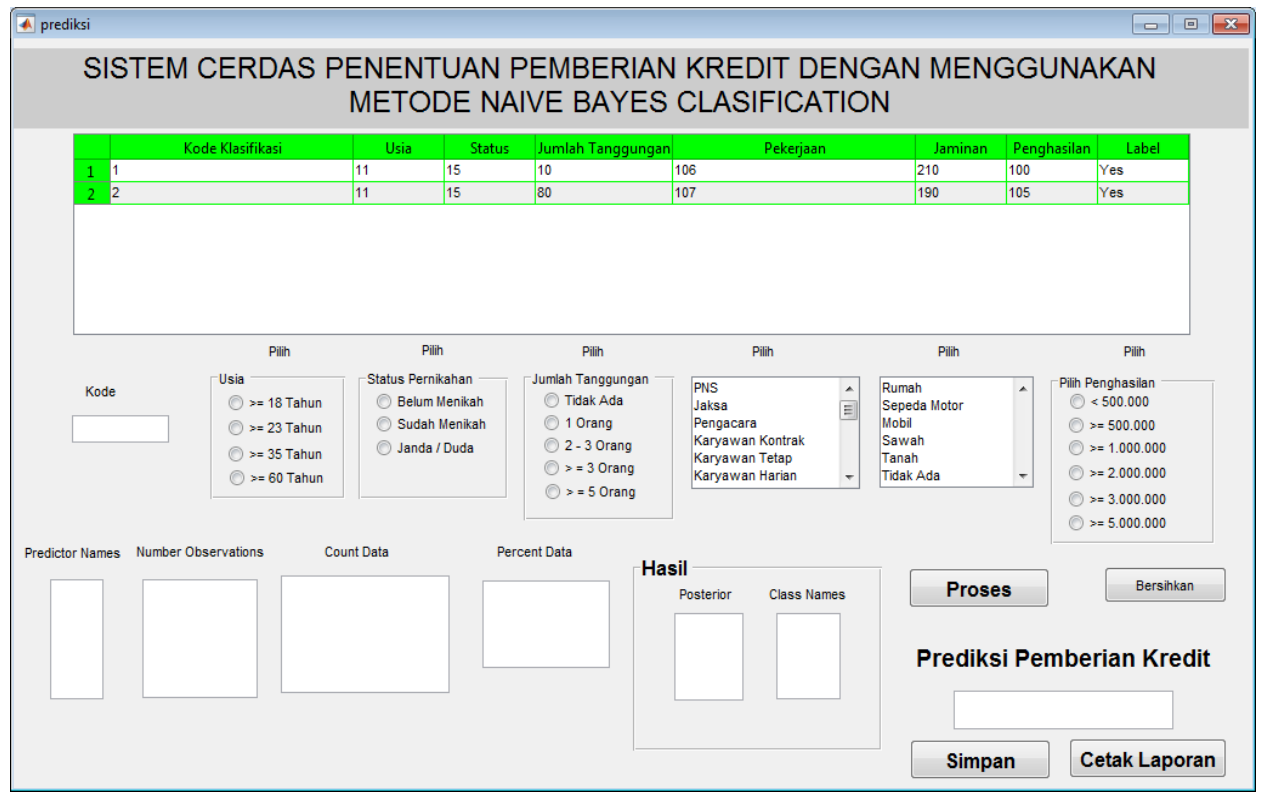

Gambar 1 Tampilan Form Penklasifikasian

Form klasifikasi pada tampilan gambar 3 diatas berfungsi untuk meklasifikasikan nasabah kedalam dua kelas yaitu antara Yes dan No dengan data yang telah diinputkan terlebih dahulu, dimana data tersebut sesuai dengan data nasabah. Gambar 1 diatas memliki beberpa tombol diantaranya yaitu:

Database : merupakan tampilan data nasabah

1. Untuk tampilan atribut memiliki arti dan cara kerja yang sama yaitu sebagai atribut pilihan yang disediakan sistem sebagai acuan dalam pengklasifikasian

2. Tombol bersihkan : tombol ini mempunyai untuk menghapus data ketika salah menginputkan ataupun ingin mengklasifikasikan data baru.

Suriana, Sistem Cerdas Penentuan Pemberian Kredit Dengan Menggunakan Metode Nä̈ve Bayes Clasification 
3. Tombol proses : tombol ini berfugsi sebagai perintah untuk melakukan perhitungan atau pemprosesan. Seperti pada gambar pemprosesan untuk hasil Yes

4. Predictor name : adalah kotak isian yang berisi jumlah variabel. Pada sistem ini jumlah variabelnya ada 6 . Kotak ini berfungsi sebagai perkalian matriks untuk setiap sub atribut.

5. Number observation : adalah kotak isian yang berisi data latih yang terdapat pada data base.

6. Count data : merupakan kotak isian yang berisi jumlah data yang yes dan jumlah data yang no

7. Precent data: merupakan kotak isian yang berisi hasil perhitungan presentasi terdapat dua hasil perentasi yaitu ada presentasi untuk hasil yes dan presentasi untuk hasil no

8. Hasil postarior: merupakan kotak isian yang menyatakan hasil perhitungan yes dan no dalam bentuk bilangan asli.

9. Prediksi pemberian kredit : terdapat kotak isian yang akan menyatakan yes atau no sesuai dengan hasil perhitungan yang dilakukan sistem.

10. Tombol simpan barfungsi unutk menyimpan data uji atau data klasifikasi

11. Tombol cetak laporan berfumgsi untuk mencetak laporsn hasil prediksi

\subsection{Pengujian}

Pengujian ini dilakukan dengan cara melakukan uji coba terhadap sistem secara satu persatu apakah sistem membaca sesuai dengan yang diharapkan atau tidak. Adapun hasil percobaan data uji yang diujikan secara satu persatu dapat dilihat pada tabel 4 dibawah ini:

Tabel 4 Hasil Pengujian Data Uji

\begin{tabular}{cllllllll}
\hline No & STATUS & USIA & $\begin{array}{c}\text { JT } \\
\text { (ORANG) }\end{array}$ & PEKERJAAN & JAMINAN & PENGHASILAN & KELAS & $\begin{array}{c}\text { HASIL } \\
\text { UJI }\end{array}$ \\
\hline 1 & Janda/Duda & $>=18$ & tidak ada & KH & Sawah & $>=2.000 .000$ & YES & sesuai \\
2 & Janda/Duda & $>=18$ & l orang & WKI & Motor & $<500.000$ & NO & sesuai \\
3 & Menikah & $>=18$ & l orang & GS & Motor & $>=5.000 .000$ & YES & tidak \\
4 & Menikah & $>=18$ & $>=3$ orang & ART & Tanah & $>=! .000 .000$ & NO & sesuai \\
5 & Menikah & $>=23$ & tidak ada & KT & Mobil & $>=5.000 .000$ & YES & tidak \\
6 & Menikah & $>=23$ & $>=5$ orang & WM & Rumah & $>=! .000 .000$ & YES & sesuai \\
7 & B. Menikah & $>=23$ & tidak ada & Pengacara & Mobil & $>=3.000 .000$ & NO & tidak \\
8 & Menikah & $>=23$ & $>=3$ orang & ART & Tanah & $>=500.000$ & NO & tidak \\
9 & Menikah & $>=35$ & tidak ada & KT & Mobil & $>=! .000 .000$ & YES & tidak \\
10 & Janda/Duda & $>=35$ & $2-3$ orang & KH & Sawah & $>=2.000 .000$ & NO & sesuai \\
11 & Menikah & $>=35$ & $>=5$ orang & WM & Rumah & $>=5.000 .000$ & YES & Sesuai \\
12 & Menikah & $>=35$ & l orang & GS & Motor & $>=5.000 .000$ & YES & Sesuai \\
13 & B. menikah & $>=35$ & l orang & KT & Motor & $>=3.000 .000$ & NO & Sesuai \\
14 & Janda/Duda & $>=35$ & $2-3$ orang & KH & Sawah & $>=500.000$ & NO & Sesuai \\
15 & Janda/Duda & $>=35$ & $2-3$ orang & KH & Sawah & $>=1.000 .000$ & NO & tidak \\
16 & Menikah & $>=60$ & $>=3$ orang & WK & Tanah & $>=500.000$ & YES & Sesuai \\
\hline
\end{tabular}

Tabel 5 Matriks Konfusi Pengujian Pada k = 1

\begin{tabular}{lllll}
\hline$f_{i j}$ & & \multicolumn{3}{l}{ Kelas Hasil Klasifikasi } \\
& & Kelas YES & Kelas NO & jumlah \\
\hline \multirow{3}{*}{ Kelas Asli } & Kelas YES & 5 & 3 & - \\
& $\begin{array}{l}\text { Kelas NO } \\
\text { jumlah }\end{array}$ & 3 & 5 & - \\
\hline
\end{tabular}


Pengujian dilakukan untuk mencari tingkat keakurasian yang dihasilkan apakah sistem ini tergolong baik. Metode pengujian yang digunakan adalah metode holdout. Dari 16 data tesing yang diujikan didapat 10 data yang sesuai dan didapatlah hasil keakurasiannya $62.50 \%$.

\section{KESIMPULAN}

Berdasarkan hasil implemtasi metodelogi CRISP-DM dan Naïve Bayes Clasification pada sistem cerdas penentuan pemberian kredit untuk instansi BUMDES dapat disimpulkan beberapa hal sebagai berikut

Sistem cerdas penentuan pemberian kradit dengan menggunakan metode Najve Bayes Clasification membantu instansi dalam pengambilan keputusan dengan cepat dalam menentukan nasabah yang berhak diberi pinjaman, dengan tingkat keakurasian sistem yaitu $62,50 \%$. Selain itu dengan adanya sistem cerdas pemberian kredit ini membantu pihak istansi untuk tidak terlalu curiga kepada nasabah yang melakukan pinjaman dikarenkan ketidaksesuaian dalam membayar pinjaman. Sehingga sedikit mengurangi resiko kredit. Sistem ini dirancang dengan meneliti datadata atau kasus-kasus yang telah terjadi sebelumnya. Untuk nasabah yang diberi pinjaman kemungkinan akan membayar pinjamannya sehingga dapat membantu pelaporan instansi tersebut.

\section{REFERENSI}

[1] Kurniawan, D., \& Supriyanto, D. C. (2013). Optimasi Algoritma Support Vector Machine (Svm) Menggunakan Adaboost Untuk Penilaian Risiko Kredit. Jurnal Teknologi Informasi, 9(1), 3849.

[2] Ndaumanu, R. I., \& Arief, M. R. (2014). Analisis Prediksi Tingkat Pengunduran Diri Mahasiswa dengan Metode K-Nearest Neighbor, 1(1). 1-15

[3] Suwondo, A. (2014). Aplikasi Sistem Informasi Perpustakaan Di Smk Takhassus Kalibeber Wonosobo, 31-39.

[4] Husni, M. R. \& Ardi, W. (2017). Implementasi Algoritma Naïve Bayes Dalam Penentuan Pemberian Kredit. Jurnal Pseudocode, 4(2), 120-128

[5] Supriyanti, W., Kusrini., Armadyah, A. (2016). Perbandingan Kinerja Algoritma C4.5 dan Naïve Bayes Untuk Ketepatan Pemilihan Konsentrasi Mahasiswa. Jurnal INFORMA, 1 (3), 61-67

[6] Anam, C \& Harry, B. S. (2018). Perbandingan Kinerja Algoritma C4.5 dan Naïve Bayes Untuk Penerimaan Beasiswa. 8(1). 13-19

[7] Eko, R., P., Suparti., Rita, R. (2014). Perbandingan Metode Klasifikasi Naïve Bayes dan KNearest Neighbor Pada Analisis Data Status Kerja Di Kabupaten Demak Tahun 2012. Jurnal GAUSSIAN, 3(4). 831-838

[8] Zelfriyenni, \& Ira, U., Y. (2014). Kebijakan Pemberian Kredit Terhadap Penetapan Jumnlah Kredit. Jurnal Edik Informatika, 1(i1). 72-80.

[9] Destiningrum, M, \& Qadhli, J., A. (2017). Sistem Informasi Penjadwalan Dokter Berbasis Web Dengan Menggunakan Framework Codelgniter. Jurnal Teknoinfo, 11(2). 30-36

[10] Yuliansyah, H. (2014). Perancangan Reflikasi Basis Data My SQL dengan Mekanisme Pengamanan Menggunakan SSL Encryption. Jurnal Informatika, 8 (11). 826-835

[11] Hasan, maryam. (2017). Prediksi Tingkat Kehancuran Pembayaran Kredit Bank Menggunakan Algoritma Naïve Bayes Berbasis Forward Selection, 9(3)· 317-323

[12] Taufik, M. (2015). Sistem Informasi Dokter Berbasis Web, 21(1). 18-23

[13] Pato, saduldyn. (2013). Pemberian Kredit Mikro Pada Bank Syariah Mandiri Cabang Manado. 1(4). $875-885$

Suriana, Sistem Cerdas Penentuan Pemberian Kredit Dengan Menggunakan Metode Naïve Bayes Clasification 
[14] Annur, Haditsah. (2018). Klasifikasi Masyarakat Iskin Menggunakan Metode Naïve Bayes. 10(2). 160-165

[15] Minarianti, Ika. (2015). Klasifikasi Data Mining Dalam Penentuan Pemberian Kredit Bagi Nasabah Koperasi. 1(1). 36-45

[16] Nuraeni, Nia.(2017). Penentuan Kelayakan Kredit Dengan Menggunakan Algoritma Naïve Bayes Classifier (Studi Kasus Bank Maya Pada Mitra Usaha Cabang PGC. 3(1). 9-14 